\title{
KEUNTUNGAN USAHA BUDIDAYA PEPAYA CALINA IPB 9 DI KECAMATAN PANYABUNGAN BARAT KABUPATEN MANDAILING NATAL PROVINSI SUMATERA UTARA
}

\author{
Oleh \\ Muhammad Ardiansyah \\ Manajemen Bisnis Syariah, STAIN Mandailing Natal \\ Email: mardiansyah@stain-madina.ac.id
}

\begin{abstract}
Abstrak
Pertanian merupakan sektor utama ekonomi masyarakat di Kecamatan Panyabungan Barat Kabupaten Mandailing Natal Provinsi Sumatera Utara, salah satu yang lagi populer dikalangan petani saat ini adalah usaha budidaya pepaya calina IPB 9. Pada umumnya para petani belum pernah melakukan analisa Keuntungan dari usaha budidaya pepaya calina IPB 9, mereka hanya mendengar dan melihat hasil dari petani yang terlebih dahulu melakukan usaha budidaya pepaya calina IPB 9 tanpa ada analisa perhitungan keuntungan langsung mengikuti jejak petani tersebut. Penelitian ini bertujuan untuk mengetahui keuntungan usaha budidaya pepaya calina IPB 9 di Kecamatan Panyabungan Barat, Kabupaten Mandailing Natal. Metode penentuan daerah penelitian ini dilakukan secara sengaja atau metode purposive. Pelaksanaan penelitian ini dilakukan dengan metode sensus yaitu mengamati individu dari suatu populasi, atau pengamatan keseluruhan dengan populasi sebanyak 22 Petani secara keseluruhan petani dijadikan responden. Dari hasil penelitian didapat rata-rata modal usaha budidaya pepaya calina IPB 9 per hektar dengan hasil panen yang didapat selama 1 priode (36 bulan). Hasil penelitian menunjukkan bahwa dalam 11 bulan sudah Break Even Point (BEP) dan pay back priode didapat pada saat tanaman berumur 13 bulan dengan nilai R/C Ratio sebesar 1,57. Dengan demikian untuk masa sekarang ini usaha budidaya pepaya calina IPB 9 di Kecamatan Panyabungan Barat masih menguntungkan.

Kata Kunci: Break Even Point (BEP), Pay Back Priode, Pepaya Calina IPB 9 \& Mandailing Natal.
\end{abstract}

\section{PENDAHULUAN}

Pertanian merupakan sektor utama ekonomi masyarakat di Indonesia hal ini didasari oleh lahan pertanian yang luas, subur, dan faktor iklim yang mendukung. Pemerintah juga memberikan perhatian yang cukup besar dalam sektor pertanian ini. Salah satu pengembangan sektor pertanian saat ini adalah budidaya tanaman buah-buahan tropika. Salah satunya budidaya pepaya Calina IPB 9.

Pepaya merupakan tanaman buah berupa herba dari famili Caracecae dan merupakan komoditi hortikultura yang mempunyai nilai ekonomis yang tinggi. Salah satu prasyarat perkembangan budidaya pepaya adalah penggunaan varietas unggul dan benih yang bermutu varietas pepaya yang bisa meningkatkatkan hasil produksi, yaitu Pepaya Calina IPB 9. Buah pepaya
(Carica papaya L.) merupakan buah yang dapat dibudidayakan di daerah tropis asal Meksiko Selatan, mempunyai nilai ekonomis tinggi, dan banyak digemari masyarakat baik dalam maupun luar Indonesia (Sujiprihati dan Suketi 2014). Dimana pepaya ini merupakan hasil pemuliaan tanaman dari pusat kajian buahbuahan tropika Institut Pertanian Bogor ( PKBT) - IPB dengan nama IPB 9 atau Calina. Menurut Isnawan, (2011), pepaya California merupakan jenis pepaya yang memiliki keunggulan antara lain, buahnya tidak terlalu besar dengan ukuran ukuran buah pepaya antara 0,8-2 kg/buah, berkulit tebal, halus dan mengkilat, berbentuk lonjong, buah matangnya berwarna kuning, rasanya manis, dan daging buahnya kenyal. Menurut (Purnadi, Widhiandono, \& Darmawan, 2017) Tanaman 
pepaya kalifornia relatif mudah ditanam, minim hama penyakit, harga bibit yang murah, waktu tanam sampai berbuah juga sangat singkat yaitu sekitar 7 bulan serta tanaman dapat berbuah selama 3 tahun (36 bulan). Suyanti, Setyadjit, dan Arif (2018) menambahkan bahwa buah pepaya dipanen 163 hari setelah bunga mekar atau setelah kulit buahnya berwarna merah 25 $30 \%$. Kriteria kematangan pepaya dapat dilihat dari warna kulit pepaya, tekstur dan tingkat kemanisannya. Perlakuan perbedaan waktu panen dapat memberikan analisis bahwa waktu pemanenan akan mempengaruhi tingkat kematangan buah. Pepaya memiliki tujuh stadia kematangan buah, yaitu matang fisiologis (mature green), semburat kuning (colour break), 25\% kuning (quarter ripe), 50\% kuning (halp ripe), 75\% kuning (ripe), 100\% kuning (full ripe), dan terlalu matang (over ripe). Panen yang tepat yaitu buah pepaya yang sudah tua dengan kondisi buah $95 \%$ berwarna hijau, disertai semburat warna kuning diantara tengah dan ujung pepaya. Penampakan luar buah kelihatan mengkal, tetapi apabila dibelah bagian dalamnya sudah menunjukkan warna merah kekuningan (Sujiprihati dan Suketi, 2014). Sehingga buah pepaya ini sangat menjanjikan untuk dijadikan buah ekspor mengingat Indonesia merupakan salah satu negara importir buah tropika selain itu Tanaman ini dapat tumbuh subur sepanjang tahun (tanpa mengenal musim) di Indonesia. Dengan menanam pepaya california atau Calina IPB 9 diharapkan bisa meningkatkan pendapatan petani. Pepaya Calin IPB 9 mulai diminati Petani di Kecamatan Panyabungan Barat dikarenakan harga getah pohon karet yang terus melemah dan tidak menguntungkan lagi, membuat para petani harus memutar otak dan melihat petani lain yang sukses mencoba terlebih dahulu melakukan usaha budidaya pepaya Calina IPB 9 di Desa Runding, Kecamatan Panyabungan Barat, Kabupaten Mandailing Natal, Provinsi Sumatera Utara. Dari salah satu Desa yang ada di Kecamatan
Panyabungan Barat itu Usaha Budidaya Pepaya Calina IPB 9 itu menyebar ke seluruh Desa di Kecamatan Panyabungan Barat dan Kecamatan lain di Kabupaten Mandailing Natal.

Pada umumnya para petani belum pernah melakukan analisa Keuntungan dari usaha budidaya pepaya Calina IPB 9, mereka hanya mendengar dan melihat hasil dari petani yang terlebih dahulu melakukan usaha budidaya pepaya Calina IPB 9 tanpa ada analisa perhitungan Keuntungan langsung mengikuti jejak petani tersebut. Dengan dasar yang tidak jelas petani-petani yang hanya langsung ikut tanpa membuat analisa perhitungan akan terancam kerugian. Hal ini sangat berisiko mengingat kebutuhan ekonomi yang semakin banyak sementara pemasukan semakin minim akan menyebabkan tingkat kemiskinan dari petani akan bertambah. Petani tersebut tidak mempunya waktu dan metode yang jelas untuk dapat melakukan analisis terhadap keuntungan Usaha Budidaya Calina IPB 9. Maka dari itulah penulis tertarik untuk melakukan penelitian dengan judul: "Keuntungan Usaha Budidaya Pepaya Calina IPB 9 di Kecamatan Panyabungan Barat Kabupaten Mandailing Natal Provinsi Sumatera Utara" yang bertujuan untuk mengetahui keuntungan usaha budidaya Pepaya Calina IPB 9 di Kecamatan Panyabungan Barat, Kabupaten Mandailing Natal. Hal ini akan berguna untuk petani yang belum mempunyai keberanian atau ragu untuk beralih ke Usaha Budidaya Pepaya Calina IPB 9 untuk mengetahui tentang analisa keuntungan \& Break Even Point (BEP) dan bagi petani yang sudah melakukan Usaha Budidaya pepaya Calina IPB 9 menjadikan penelitian ini sebagai referensi untuk mencapai Break Even Point (BEP).

\section{METODE PENELITIAN \\ Waktu dan Lokasi Penelitian}

Penelitian dilakukan pada bulan Januari- Juli tahun 2020, dan lokasi penelitian berada di wilayah Kecamatan Panyabungan 
Barat kabupaten Mandailing Natal provinsi Sumatera Utara. Kecamatan Panyabungan Barat berada pada geografis di dataran dengan ketinggian di atas permukaan laut 200-700 Meter, dengan Luas $87,22 \mathrm{~km}^{2}$. Penentuan daerah penelitian dilakuakan secara sengaja atau puposive. Lokasi penelitian disajikan dalam Gambar 1

Gambar 1. Lokasi penelitian di Kec. Panyabungan Barat, Mandailing Natal

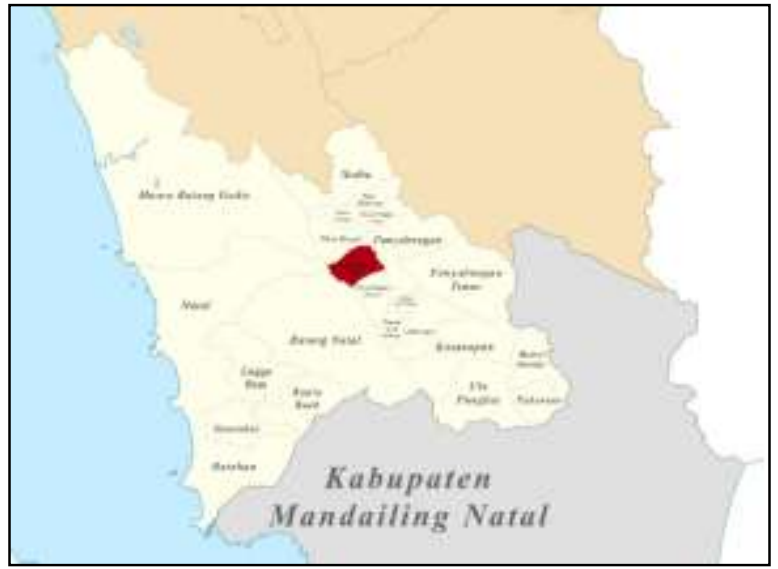

(Sumber : Wikipedia bahasa Indonesia, ensiklopedia bebas)

\section{Pengumpulan dan Analisis Data}

Penelitian ini merupakan studi kasus dimana responden dipilih secara acak, dengan jumlah responden 20 orang yang merupakan Petani Peapaya Calina IPB 9 di kecamatan Panyabungan Barat. Menurut Arikunto (2012) metode survai merupakan metode formal untuk memperoleh informasi yang sama atau sejenis dari berbagai kelompok atau orang yang terutama ditempuh dengan Observasi dan wawancara. Observasi yaitu dalam pengumpulan dan perhitungan data peneliti melakukan pengamatan langsung pada objek yang diteliti, Wawancara (interview) dengan angket (daftar pertanyaan) atau melalui wawancara. Data dikumpulkan dengan wawancara dan Data yang dikumpulkan adalah seluruh biaya (meliputi persiapan lahan, penanaman, pemeliharaan, dan pemanenan) dan pendapatan (hasil produksi pepaya) dari budidaya pepaya Analisis usaha pada penelitian ini dengan cara analisis Pay Back Periode.

\section{Analisis Biaya Produksi}

Analisi biaya produksi adalah semua biaya yang dikeluarkan oleh petani dala proses produksi (dalam hal ini meliputi biaya tetap dan biaya variabel)

a. Biaya Total $($ Total Cost $=\mathbf{T C})$

Biaya yang dikeluarkan dalam usaha budidaya untuk satukali proses produksi meliputi biaya tetap dan biaya tidak tetap. Penjumlahan kedua biaya ini disebut biaya total atau total cost. digunakan rumus sebagai berikut :

Keterangan :

$$
\mathrm{TC}=\mathrm{FC}+\mathrm{VC}
$$

$\mathrm{TC}=$ Total Cost (Jumlah Biaya)

$\mathrm{FC}=$ Fixed Cost (Biaya Tetap)

$\mathrm{VC}=$ Variable Cost (Biaya tidak tetap)

b. Biaya Tetap (Fixed Cost=FC)

Biaya tetap adalah biaya yang besarnya tidak dipengaruhi besarnya produksi. Berapapun tingkat output yang dihasilkan, besarnya selalu sama. (Shinta A, 2011;83).

Biaya tetap yaitu merupakan biaya yang diperlukan pada saat awal pembayaran yang terdiri dari sewa lahan, bunga pinjaman yang berupa uang, pajak, biaya peralatan, biaya penyusutan alat, bangunan, barang investasi lainnya. Penyusutan ini merupakan pengganti kerugian alat pengurangan nilai yang disebabkan karena waktu dan cara penggunaan dari semua modal tetap. Besarnya biaya tetap ini tidak berubah jumlahnya meskipun jumlah output pada proses produksi berubah-ubah, bahkan pada saat tidak berproduksi biaya tetap ini tetap ada.

$$
\mathrm{FC}=\mathrm{TC}-\mathrm{VC}
$$

\section{c. Biaya Tidak Tetap / Biaya Berubah Total (Total Variabel Cost $=$ TVC)}

Biaya tidak tetap yaitu biaya yang dibutuhkan pada saat proses produksi berlangsung dan bersifat Variabel atau dapat berubah-ubah sesuai dengan hasil produksi yang di hasilkan. Semakin 
banyak Produksi yang dihasilkan, maka semakin besar pula biaya yang harus dikeluarkan. Biaya tidak tetap yang diperhitungkan Semakin besar jumlah output, semakin besar biaya variabel yang dikeluarkan. (Shinta A, 2011;84). Contoh biaya tidak tetap : Biaya bibit Pepaya, Biaya Pupuk, Biaya pestisida, Biaya upah tenaga kerja, Biaya tak terduga, dan, Biaya panen.

\section{Analisis penerimaan}

$$
\mathrm{TVC}=\mathrm{TC}-\mathrm{TFC}
$$

\section{a. Pendapatan usaha budidaya}

Dengan diketahuinya jumlah penerimaan usaha budidaya (TR) dan jumlah biaya usaha budidaya (TC). Maka dapat diketahui besarnya pendapatan yaitu baik keuntungan atau kerugian usaha tani. Jadi pendapatan adalah selisih antara jumlah penerimaan dengan jumlah biaya usaha budidaya (Shinta A, 2011;88), dan bila dirumuskan sebagai berikut :

$$
\boldsymbol{\pi}=\mathbf{T R}-\mathbf{T C}
$$

Keterangan :

$\pi \quad=$ Pendapatan

TR = Total Revenue (Jumlah Penerimaan)

$\mathrm{TC}=$ Total Cost (Jumlah Biaya)

\section{b. Peneriaan Usaha budidaya}

Penerimaan usaha budidaya adalah nilai produksi yang diperoleh dalam suatu usaha budidaya. Penerimaan atau Total Revenue (TR) diperoleh dengan cara mengalikan jumlah produksi dengan harga per unitnya, hal ini dituliskan sebagai berikut :

Keterangan :

$$
\mathrm{TR}=\mathrm{P} \times \mathrm{Q}
$$

$\mathrm{TR}=$ Total penerimaan $(\mathrm{Rp} / \mathrm{ha})$

$\mathrm{P}=$ Harga hasil produksi (price)

$\mathrm{Q}=$ Jumlah produksi (quantum)

3. Periode pembayaran kembali (Pay back periode)

Pay back periode adalah priode waktu untuk mengetahui kapan pada bulan atau tahun keberapa (kapankah) seluruh biaya usaha budidaya pepaya Calina IPB 9 dapat kembali (Arifin, 2005). Seluruh petani pepaya menjual produksinya secara bertahap atau perperiodik. Dan untuk mengetahui kapan biaya produksi usaha budidaya pepaya dapat kembali dengan cara menggunakan tabel pay back periode.

\section{Analisis Imbangan Penerimaan dan Biaya (RC/Ratio)}

Menurut Soekartawi (2006:85), biaya usaha budidaya adalah semua pengeluaran yang dipergunakan dalam usaha budidaya. Biaya usaha budidaya dibedakan menjadi dua yaitu biaya tetap (Fixed Cost) dan biaya tidak tetap (Variabel Cost). Biaya tetap adalah biaya yang besarnya tidak tergantung pada besar kecilnya produksi yang akan dihasilkan, sedangkan biaya tidak tetap adalah biaya yang besar kecilnya dipengaruhi oleh volume produksi. Untuk mengetahui usaha budidaya menguntungkan atau tidak secara ekonomi dapat dianalisis dengan menggunakan nisbah atau analisi imbang antara total pendapatan dengan total biaya. R/C Ratio (Return cost Ratio) merupakan perbandingan antara penerimaan dengan biaya produksi, dengan rumus sebagai berikut:

$$
\mathrm{RC} \text { Ratio }=\frac{\mathrm{TR}}{\mathrm{TC}}
$$

Keterangan :

TR = Total Revenue (Total Penerimaan)

TC $=$ Total Cost (Total Biaya)

RC-Ratio = Return dan Cost Ratio

Adapun kriteria pengambilan keputusan menurut (Simatupang, 2002) dan (Rusastra, 1996) didalam (Siregar dan sumaryanto 2003), yang mengemukakan bahwa beberapa peneliti mengatakan usaha budidaya suatu komoditas dapat bertahan dan dikatakan layak jika penerimaan bersih bagi pengelola paling sedikit mencapai $20 \%$ dari biaya yang dikeluarkan. Proporsi atau nilai penerimaan dianggap sudah cukup mewakili seorang petani sebagai 
pengelola usaha. Berdasarkan pendapat tersebut diatas maka rumus di atas uji kelayakannya dikatakan efisien jika :

a. Jika R/C Ratio >1,2 : berarti usaha budidaya tersebut dikatakan efisien dan memberi keuntungan yang layak karena keuntungan paling sedikit $20 \%$ dari total biaya.

b. Jika $1<\mathrm{R} / \mathrm{C}$ Rasio $<1,2$ : berarti usaha budidaya menguntungkan namun belum efisien dan belum layak

c. Jika R/C Rasio < 1 : berarti usaha budidaya tidak efisien, bahkan mengalami kerugian.

d. Jika R/C Rasio $=1$ : Berarti usaha budidaya mencapai titik impas (Break Event Point) tidak efisien, bahkan mengalami kerugian. 4 . $\mathrm{R} / \mathrm{C}$ Ratio $=1$ : berarti usaha budidaya mencapai titik impas (Break Event Point) yaitu tidak untung dan juga tidak rugi.

\section{HASIL DAN PEMBAHASAN}

Karakteristik Petani Responden Umur

Berikut ini dapat dilihat umur responden yang didapatkan pada saat penelitian dilakukan.

Tabel 1. Umur Petani Responden

\begin{tabular}{|c|c|c|c|}
\hline No. & $\begin{array}{c}\text { Tingkatan } \\
\text { Umur } \\
\text { (tahun) }\end{array}$ & $\begin{array}{c}\text { Jumlah } \\
\text { Jiwa } \\
\text { (orang) }\end{array}$ & Presentase \\
$(\%)$
\end{tabular}

Sumber data : Angket

Dari tabel 1 di atas dapat diketahui jumlah responden terbanyak yang berumur 30 39 tahun $(45,00 \%)$, umur $40-49$ tahun $(30,00 \%)$, umur $20-29$ tahun sebesar (15\%), dan umur 50 - 59 tahun $(10,00 \%)$. Dari data tersebut Petani yang tergolong umur $30-39$ tahun paling banyak jumlahnya karena merupakan golongan petani muda yang ingin maju dalam mengembangkan pertanian di daerah mereka dengan jiwa yang berani untuk mencoba sesuatu hal yang baru dan lebih modern karena mereka termasuk yang sudah mengenal teknologi inovasi. Apabila ada teknologi baru, petani muda lebih mudah menerima informasi, mencari tahu lebih dalam lagi dan berani langsung mencoba menerapkan teknologi baru walaupun belum pernah mencoba sebelumnya. Rendahnya persentase kelompok yang berumur di atas 64 tahun, erat kaitannya dengan aktivitas usaha tani yang lebih banyak memerlukan kemampuan fisik. Dengan demikian petani dalam kategori umur produktif, memiliki kemampuan fisik yang memadai akan memiliki tingkat produktivitas lebih tinggi. Tingkat umur berpengaruh terhadap seseorang dalam berpikir dan memutuskan sesuatu, termasuk tingkat adopsi terhadap inovasi baru. Semakin muda umur seseorang akan menentukan tingkat keingintahuan terhadap sesuatu hal yang dianggap baru untuk mengembangkan potensi daerah mereka.

\section{Pendidikan}

Tingkat pendidikan baik formal maupun non formal besar sekali pengaruhnya terhadap penyerapan ide-ide baru, sebab pengaruh pendidikan terhadap seseorang akan memberikan suatu wawasan yang luas, sehingga petani tidak mempunyai sifat yang tidak terlalu tradisional. Jadi tingkat pendidikan masyarakat merupakan salah satu aspek yang mempengaruhi pola pikir seseorang dalam menentukan keputusan menerima inovasi baru, karena semakin tinggi tingkat pendidikan seseorang diharapkan dapat berpikir lebih baik dan mudah menyerap inovasi pertanian yang berkaitan dengan pengembangan usaha budidayanya. Mereka yang berpendidikan tinggi adalah relatif lebih cepat dalam melaksanakan adopsi inovasi. Begitu pula sebaliknya mereka yang berpendidikan rendah, agak sulit dan memakan waktu yang relatif lama untuk mengadakan perubahan. 
Tabel 2. Tingkat Pendidikan Pertani

\begin{tabular}{|c|c|c|c|}
\hline No. & $\begin{array}{c}\text { Tingkat } \\
\text { Pendidikan }\end{array}$ & $\begin{array}{c}\text { Responden } \\
\text { (orang) }\end{array}$ & $\begin{array}{c}\text { Presentase } \\
(\%)\end{array}$ \\
\hline 1 & $\begin{array}{c}\text { Sekolah } \\
\text { Dasar }\end{array}$ & 1 & 5,00 \\
\hline 2 & SLTP & 2 & 10,00 \\
\hline 3 & SLTA & 7 & 35,00 \\
\hline 4 & $\begin{array}{c}\text { Diploma/ } \\
\text { Sarjana }\end{array}$ & 10 & 50,00 \\
\hline \multicolumn{2}{|r|}{ Jumlah } & 20 & 100 \\
\hline
\end{tabular}

Sumber: Angket

Berdasarkan data pada tabel 2 di atas dapat diketahui bahwa jumlah petani responden yang menyelesaikan pendidikan diploma/ sarjana 50,00\%, pendidikan Sekolah Lanjutan Menengah Atas 35,00\%, pendidikan Sekolah Lanjutan Tingkat Pertama 10,00\%, dan hanya $5,00 \%$ yang menyelesaikan pendidikan dasar. Tingkat pendidikan responden dalam penelitian ini di dominasi oleh tingkat pendidikan Sekolah Lanjutan Menengah Atas dan Diploma/ Sarjana. Dengan demikian dapat dikatakan bahwa semakin tinggi tingkat pendidikan petani responden, semakin tinggi pula kemampuan seseorang untuk berpikir dan mengambil keputusan.

\section{Status Kepemilikan Lahan}

Status pengusahaan lahan dapat dikategorikan menjadi empat bagian, yakni :

1. Sistem sewa-menyewa

2. Sistem bagi hasil

3. Sistem gadai

4. Sistem kombinasi.

Sistem sewa merupakan pengalihan hak garap kepada orang lain dengan imbalan yang pada umumnya berupa uang tunai kepada pemilik lahan. Besarnya tingkat sewa biasanya ditentukan sesuai dengan harga pasar lahan setempat. Selanjutnya setelah transaksi sewa terjadi maka pengelolaan atas lahan dan risikonya sepenuhnya menjadi tanggung jawab penyewa. Sistem bagi hasil merupakan pengalihan hak garap kepada orang lain, dimana antara pemilik dan penggarap terjadi ikatan pengusahaan usaha budidaya dan pembagian produksi. Dalam sistem sewa, pemilik lahan menyediakan lahan sedangkan penggarap menyediakan tenaga kerja dan semua modal produksi. Siapa yang menanggung sarana produksi dan bagaimana pembagian hasil produksi tergantung dari tradisi setempat dan perjanjian sebelumnya dan bisa bagi hasil dengan hitungan $2 / 3$ hasil untuk penggarap dan $1 / 3$ untuk yang punya lahan. Sistem gadai merupakan pengalihan hak garap kepada orang lain yang sifatnya lebih sebagai jaminan atas pinjaman pemilik lahan terhadap penggarap. Dibandingkan dengan sewa, penetapan besarnya nilai lahan pada gadai tidaklah selugas sewa dan sangat tergantung kepada lamanya pemilik lahan mampu mengembalikan pinjamannya. Pada umumnya pemilik uang (dalam hal ini sebagai penggarap atau yang mengusahakan lahan tersebut) sebagai penentu harga. Sistem kombinasi merupakan sistem modifikasi bentuk pengusahaan lahan, seperti: pemilikpenyewa, pemilik-penyakap, pemilikpenggadai, penyewa-penyakap, penyewapenggadai, penyakap-penggadai dan lain sebagainya. Berdasarkan uraian di atas, dapat disimpulkan bahwa sistem penguasaan lahan dapat digolongkan ke dalam tiga kelompok besar, yaitu :

1. Petani yang mengusahakan lahan milik sendiri,

2. Petani yang mengusahakan lahan bukan milik sendiri, dan

3. Gabungan dari keduanya.

Selain itu penguasaan lahan dan pengusahaan lahan merupakan konsep yang berbeda. Penguasaan lahan merujuk pada kewenangan seseorang dalam menguasai lahannya yang diakibatkan karena memiliki, menyewa, sakap, gadai, dan pinjam. Sedangkan pengusahaan lahan merujuk pada seberapa luas pemanfaatan/penggunaan lahan yang dikuasai oleh petani. Status kepemilikan 
lahan petani responden disajikan dalam tabel 3 dibawah ini.

Tabel 3. Status Kepemilikan Lahan Responden

\begin{tabular}{|c|l|c|c|}
\hline No & $\begin{array}{c}\text { Tingkat } \\
\text { Pendidikan }\end{array}$ & $\begin{array}{c}\text { Responden } \\
\text { (orang) }\end{array}$ & $\begin{array}{c}\text { Presentase } \\
(\boldsymbol{\%})\end{array}$ \\
\hline 1 & Lahan sendiri & 6 & 30,00 \\
\hline 2 & Lahan sewa & 12 & 60,00 \\
\hline 3 & Bagi hasil & 2 & 10,00 \\
\hline \multicolumn{2}{|c|}{ Jumlah } & 20 & 100 \\
\hline
\end{tabular}

Sumber : Data primer

Dari data tabel 3 diatas menunjukkan bahwa 12 petani responden $(60,00 \%)$ merupakan petani yang mengusahakan lahan pertanian bukan milik sendiri/ sewa, 6 petani responden $(30,00 \%)$ merupakan petani petani yang mengusahan lahan pertanian milik sendiri dan 2 petani responden $(10,00 \%)$ merupakan petani yang mengusahakan bukan milik sendiri atau bagi hasil.

Analisa Biaya, Penerimaan dan Pendapatan Usaha Tani

\section{Analisa biaya}

Biaya produksi usaha budidaya pepaya Calina IPB 9 adalah biaya yang dikeluarkan petani responden pepaya Calina IPB 9 selama proses produksi hingga menjadi produk buah pepaya Calina IPB 9. Menurut (Soekartawi, 2006;85). Biaya usaha budidaya meliputi biaya tetap (Fixed Cost) dan biaya tidak tetap (Variable cost). Biaya tetap (Fixed cost) meliputi pembukaan lahan, sewa lahan, selama musim tanam usaha budidaya pepaya Calina. Biaya tidak tetap (Variabel cost) meliputi biaya benih, biaya pupuk, biaya obat-obatan, dan biaya tenaga kerja dll.

1. Biaya tetap (Biaya investasi/Fixed Cost=FC)

Biaya tetap dalam usaha budidaya pepaya Calina IPB 9 ini meliputi peralatan/perlengkapan dan sewa lahan. Peralatan/perlengkapan dalam hal ini segala jenis alat-alat pertanian yang dibutuhkan untuk usaha budidaya pepaya Calina IPB 9. Sewa Lahan adalah biaya yang dikeluarkan oleh petani kepada pemilik lahan. Dari tabel 3 Kita ketahui $60,00 \%$ responden merupakan petani yang mengusahakan lahan pertanian bukan milik sendiri/ sewa. Oleh sebab itu kita akan menghitung biaya sewa lahan kedalam Biaya tetap. untuk Sewa yang dikeluarkan oleh petani responden adalah Rp. Rp.7.500.000 s/d 9.500.000/Ha. Dan kita rata kan Sewa Lahan Rp. 8.500.000/Ha.

Tabel 4. Biaya Tetap (Fixed Cost) Rata-rata Usaha Budidaya pepaya Calina IPB 9 Per Ha

\begin{tabular}{|c|c|c|c|c|}
\hline No. & Uraian & $\begin{array}{c}\text { Kebutu } \\
\text { han } \\
\text { Per Ha }\end{array}$ & \begin{tabular}{|c|} 
Harga \\
Satuan \\
$(\mathbf{R p})$
\end{tabular} & $\begin{array}{c}\text { Jumlah } \\
\text { (Rp) }\end{array}$ \\
\hline \multirow[t]{7}{*}{1} & Peralatan & & & \\
\hline & Sprayer & 1 Unit & $\begin{array}{r}450.00 \\
0\end{array}$ & 450.000 \\
\hline & Cangkul & $2 \mathrm{Bh}$ & $\begin{array}{r}100.00 \\
0\end{array}$ & 200.000 \\
\hline & Skop & $2 \mathrm{Bh}$ & $\begin{array}{r}100.00 \\
0 \\
\end{array}$ & 200.000 \\
\hline & Parang & $2 \mathrm{Bh}$ & 80.000 & 160.000 \\
\hline & Pisau & $1 \mathrm{Bh}$ & 40.000 & 40.000 \\
\hline & $\begin{array}{l}\text { Beko } \\
\text { Sorong }\end{array}$ & 1 Unit & $\begin{array}{r}450.00 \\
0 \\
\end{array}$ & 450.000 \\
\hline \multicolumn{4}{|c|}{ Jumlah Total } & 1.500 .000 \\
\hline 2 & $\begin{array}{l}\text { Biaya } \\
\text { Sewa }\end{array}$ & & & \\
\hline & Lahan & 1 Thn & \begin{tabular}{|r|}
8.500 .00 \\
0 \\
\end{tabular} & 8.500 .000 \\
\hline & Lahan & 2 Thn & $\begin{array}{r}8.500 .00 \\
0 \\
\end{array}$ & 17.000 .000 \\
\hline & Lahan & 3 Thn & $\begin{array}{r}8.500 .00 \\
0 \\
\end{array}$ & 25.500 .000 \\
\hline
\end{tabular}

Sumber : Data Primer

Dari tabel 4 diatas dapat kita ketahui biaya rata-rata peralatan per $\mathrm{Ha}$ adalah $\mathrm{Rp}$ 1.500.000 dan untuk rata-rata sewa yang dikeluarkan oleh petani responden selama 7 s/d 12 bulan sebesar Rp. 10.000.000, Biaya tetap selama 1 priode produksi (36 Bulan) adalah Rp. 27.000.000. 
2. Biaya tidak tetap (Biaya eksploitasi /Variabel Cost $=$ VC)

Di Daerah penelitian biaya variabel (biaya tidak tetap) untuk memproduksi tanaman pepaya Calina IPB 9 adalah biaya yang dialokasikan untuk membeli input variabel seperti biaya tenaga kerja, pupuk, bibit, dan, pestisida. Biaya Upah tenaga kerja meliputi terbagi tiga tahap yatu :

1. Tahap Awal dimana pada tahap ini Biaya Pembukaan lahan, Biaya Pengolahan Lahan, dan Biaya Penanaman Pepaya.

2. Tahap Perawatan dimana Biaya Perawatan yang dikeluarkan selama 1 priode (36 Bulan),

3. Tahap Produksi dimana pada tahap ini yang dikeluarkan Biaya Panen. Biaya tenaga kerja dapat kita lihat pada Tabel. 5

Tabel 5. Biaya Tenaga Kerja (Biaya tidak tetap/ Variabel Cost) Rata-rata Usaha Budidaya pepaya Calina IPB 9 Per Ha

\begin{tabular}{|c|c|c|c|c|}
\hline No & Uraian & $\begin{array}{l}\text { Kebutuhan } \\
(\mathrm{Rp} / \mathrm{Ha})\end{array}$ & $\begin{array}{c}\text { Masa } \\
\text { Waktu } \\
\text { (Kali/Bln) }\end{array}$ & $\begin{array}{l}\text { Jumlah } \\
\text { (Rp) }\end{array}$ \\
\hline 1 & Tahap Awal & & & \\
\hline & Pembukaan & 3.000 .000 & 1 & 3.000 .000 \\
\hline & Pengolahan & 3.500 .000 & 1 & 3.500 .000 \\
\hline & Penanaman & 1.400 .000 & 1 & 1.400 .000 \\
\hline \multicolumn{4}{|c|}{ Jumlah } & 7.900 .000 \\
\hline \multirow[t]{6}{*}{2} & $\begin{array}{l}\text { Tahap } \\
\text { Perawataan }\end{array}$ & & & \\
\hline & Bulan & 1.600 .000 & 7 & 11.200 .000 \\
\hline & Bulan & 1.600 .000 & 9 & 14.400 .000 \\
\hline & Bulan & 1.600 .000 & 11 & 17.600 .000 \\
\hline & Bulan & 1.600 .000 & 13 & 20.800 .000 \\
\hline & Bulan & 1.600 .000 & 36 & 57.600 .000 \\
\hline \multirow[t]{2}{*}{3} & $\begin{array}{l}\text { Tahap } \\
\text { Produksi }\end{array}$ & & & \\
\hline & Panen & 0 & 29 & 0 \\
\hline \multicolumn{4}{|c|}{ Jumlah Total 36 Bulan ( 1 Priode) } & 65.500 .000 \\
\hline
\end{tabular}

Sumber : Data Primer

Dari tabel 5 diatas menunjukkan tahap Awal Pembukaan Lahan biaya tenaga kerja sebesar Rp. 2.500.000 s/d Rp. 3.500.000/Ha. Hal ini berbeda tergantung kesulitan pembersihan oleh sebab itu dapat kita rataratakan Rp. 3.000.000/Ha. Pengolahan Lahan biaya tenaga kerja yang dikeluarkan adalah $\mathrm{Rp}$. 3.000.000 s/d 4.000.000 tergantung situasi kondisi lahan dan kita rata-ratakan menjadi Rp. 3.500.000 dan biaya tenaga kerja untuk penanaman pepaya Calina IPB 9 Rata-rata Rp. 1.400.000 untuk 1.400 batang dan sudah termasuk biaya penambalan yang mati pada saat tahap penanaman pertama dan total pembiayaan pada tahap awal ini adalah Rp. 7.900.000. Pada tahap perawatan pada tabel 5 kita dapat melihat biaya tenaga kerja perawatan perbulan dari 3 bulan sampai 36 bulan atau 1 masa priode produksi. Dengan total biaya perawatan adalah Rp. 65.500.000 selama 36 bulan. Pada tahap produksi atau panen berhubung di lokasi penelitian biaya panen yang menanggung adalah Pembeli maka biaya dianggap tidak ada.

Untuk biaya rata-rata bibit, pupuk, dan peptisida yang dikeluarkan petani pepaya Calina IPB 9 Kecamatan Panyabungan Barat Kabupaten Mandailing Natal dapat dilihat pada tabel 6 sebagai berikut :

Tabel 6. Rata-Rata Biaya Variabel bibit, pupuk, dan peptisida Perhektar Usaha budidaya Pepaya Calina IPB 9 di Kecamatan Panyabungan Barat, Kabupaten Mandailing Natal

\begin{tabular}{|c|l|r|r|r|r|}
\hline No & Uraian & \multicolumn{1}{|c|}{$\begin{array}{l}\text { Kebutuhan } \\
\text { (Ha) }\end{array}$} & $\begin{array}{c}\text { Harga } \\
\text { Satua } \\
\text { n (Rp) }\end{array}$ & \multicolumn{1}{|l|}{$\begin{array}{c}\text { Jumlah } \\
(\mathbf{R p})\end{array}$} \\
\hline $\mathbf{1}$ & \multicolumn{4}{|l|}{ Biaya sampai 7 bulan } \\
\hline & Bibit & 1.800 & $\mathrm{Btg}$ & 5.000 & 9.000 .000 \\
\hline & $\begin{array}{l}\text { Pupuk } \\
\text { ZA }\end{array}$ & 525 & $\mathrm{Kg}$ & 3.500 & 1.837 .500 \\
\hline & $\begin{array}{l}\text { Pupuk } \\
\text { TSP }\end{array}$ & 490 & $\mathrm{Kg}$ & 6.500 & 3.185 .000 \\
\hline & $\begin{array}{l}\text { Pupuk } \\
\text { KCL }\end{array}$ & 357 & $\mathrm{Kg}$ & 7.000 & 2.499 .000 \\
\hline & $\begin{array}{l}\text { Pupuk } \\
\text { SS }\end{array}$ & 2 & $\mathrm{Zak}$ & 350.000 & 700.000 \\
\hline & $\begin{array}{l}\text { Kalsiu } \\
\text { m }\end{array}$ & 30 & $\mathrm{Kg}$ & 15.000 & 450.000 \\
\hline
\end{tabular}




\begin{tabular}{|c|c|c|c|c|c|c|c|c|c|c|c|}
\hline & Borate & 20 & $\mathrm{Kg}$ & 20.000 & 400.000 & & $\begin{array}{l}\text { Convid } \\
\text { er }\end{array}$ & 4 & $\mathrm{Bh}$ & 35.000 & 140.000 \\
\hline & $\begin{array}{l}\text { Delomi } \\
\mathrm{t}\end{array}$ & 20 & Zak & 25.000 & 500.000 & & $\begin{array}{l}\text { Gandas } \\
\text { il }\end{array}$ & 4 & $\mathrm{Bh}$ & 30.000 & 120.000 \\
\hline & $\begin{array}{l}\text { Pupuk } \\
\text { Kompo } \\
\text { s }\end{array}$ & 450 & Zak & 10.000 & 4.500 .000 & & $\begin{array}{l}\text { Antoni } \\
\mathrm{k}\end{array}$ & 2 & $\mathrm{Bh}$ & 55.000 & 110.000 \\
\hline & Pupuk & 20 & $7 \mathrm{ak}$ & & & & $\begin{array}{l}\text { Antrac } \\
\text { ol }\end{array}$ & 2 & $\mathrm{Bh}$ & 50.000 & 100.000 \\
\hline & & & & 125.000 & 2.500 .000 & & Hantu & 1 & Btl & 60.000 & 60.000 \\
\hline & Regen & 15 & Btl & 35.000 & 525.000 & & Ronda & 1 & Ltr & & \\
\hline & Lannat & 15 & $\mathrm{Ph}$ & & & & & & & 75.000 & 75.000 \\
\hline & $\mathrm{e}$ & 15 & Dil & 35.000 & 525.000 & & \multicolumn{4}{|c|}{ Jumlah total } & 36.081 .500 \\
\hline & $\begin{array}{l}\text { Termo } \\
\text { stok }\end{array}$ & 15 & Btl & 35000 & 525000 & 4 & \multicolumn{4}{|c|}{ Biaya sampai 13 bulan } & \\
\hline & Convid & 15 & $\mathrm{Bh}$ & 35.000 & $\begin{array}{l}525.000 \\
525.000\end{array}$ & & $\begin{array}{l}\text { Pupuk } \\
\text { ZA }\end{array}$ & 140 & $\mathrm{Kg}$ & 3.500 & 490.000 \\
\hline & Gandas & 15 & $\mathrm{Bh}$ & 30.000 & 450.000 & & $\begin{array}{l}\text { Pupuk } \\
\text { TSP }\end{array}$ & 105 & $\mathrm{Kg}$ & 6.500 & 682.500 \\
\hline & Antoni & 10 & $\mathrm{Bh}$ & \multirow{2}{*}{55.000} & \multirow{2}{*}{550.000} & & $\begin{array}{l}\text { Pupuk } \\
\text { KCL }\end{array}$ & 105 & $\mathrm{Kg}$ & 7.000 & 735.000 \\
\hline & & & & & & & Pupuk & 1 & $7 \mathrm{ak}$ & & \\
\hline & $\begin{array}{l}\text { Antrac } \\
\text { ol }\end{array}$ & 10 & $\mathrm{Bh}$ & 50.000 & 500.000 & & & 1 & ZaK & 350.000 & 350.000 \\
\hline & Hantu & 5 & Btl & 60.000 & 300.000 & & $\begin{array}{l}\text { Kalsiu } \\
\text { m }\end{array}$ & 10 & $\mathrm{Kg}$ & 15.000 & 150.000 \\
\hline & Ronda & 6 & Ltr & 75000 & 450.000 & & Borate & 8 & $\mathrm{Kg}$ & 20.000 & 160.000 \\
\hline & \multirow{2}{*}{\multicolumn{4}{|c|}{ Jumlah total }} & \multirow{3}{*}{29.921 .500} & & Regen & 4 & Btl & 35.000 & 140.000 \\
\hline & & & & & & & Lannat & 4 & $\mathrm{Bh}$ & & \\
\hline 2 & \multicolumn{4}{|c|}{ Biaya sampai 9 bulan } & & & & 4 & Bn & 35.000 & 140.000 \\
\hline & $\begin{array}{l}\text { Pupuk } \\
\text { ZA }\end{array}$ & 140 & $\mathrm{Kg}$ & 3.500 & 490.000 & & $\begin{array}{l}\text { Termo } \\
\text { stok }\end{array}$ & 4 & Btl & 35.000 & 140.000 \\
\hline & $\begin{array}{l}\text { Pupuk } \\
\text { TSP }\end{array}$ & 105 & $\mathrm{Kg}$ & 6.500 & 682.500 & & $\begin{array}{l}\text { Convid } \\
\text { er }\end{array}$ & 4 & $\mathrm{Bh}$ & 35.000 & 140.000 \\
\hline & $\begin{array}{l}\text { Pupuk } \\
\text { KCL }\end{array}$ & 105 & $\mathrm{Kg}$ & 7.000 & 735.000 & & $\begin{array}{l}\text { Gandas } \\
\text { il }\end{array}$ & 4 & $\mathrm{Bh}$ & 30.000 & 120.000 \\
\hline & $\begin{array}{l}\text { Pupuk } \\
\text { SS }\end{array}$ & 1 & Zak & 350.000 & 350.000 & & $\begin{array}{l}\text { Antoni } \\
\mathrm{k}\end{array}$ & 2 & $\mathrm{Bh}$ & 55.000 & 110.000 \\
\hline & $\begin{array}{l}\text { Kalsiu } \\
\mathrm{m}\end{array}$ & 10 & $\mathrm{Kg}$ & 15.000 & 150.000 & & $\begin{array}{l}\text { Antrac } \\
\text { ol }\end{array}$ & 2 & $\mathrm{Bh}$ & 50.000 & 100.000 \\
\hline & Borate & 8 & $\mathrm{Kg}$ & 20.000 & 160.000 & & Hantu & 1 & Btl & 60.000 & 60.000 \\
\hline & \multicolumn{4}{|c|}{ Jumlah total } & 32.489 .000 & & $\begin{array}{l}\text { Ronda } \\
p\end{array}$ & 1 & Ltr & 75.000 & 75.000 \\
\hline 3 & \multicolumn{4}{|c|}{ Biaya sampai 11 bulan } & & & Pupuk & & & & \\
\hline & $\begin{array}{l}\text { Pupuk } \\
\text { ZA }\end{array}$ & 140 & $\mathrm{Kg}$ & 3.500 & 490.000 & & $\begin{array}{l}\text { Kompo } \\
\mathrm{s}\end{array}$ & 450 & Zak & 10.000 & 4.500 .000 \\
\hline & $\begin{array}{l}\text { Pupuk } \\
\text { TSP }\end{array}$ & 105 & $\mathrm{Kg}$ & 6.500 & 682.500 & & \multicolumn{4}{|c|}{ Jumlah total } & 44.174.000 \\
\hline & Pupuk & 105 & & \multirow[b]{2}{*}{7.000} & \multirow[b]{2}{*}{735.000} & 5 & & \\
\hline & KCL & 105 & $\mathrm{Kg}$ & & & & Pupuk & 1540 & & Biaya sampai 36 bulan & \\
\hline & Pupuk & 1 & $7 \mathrm{ak}$ & & & & $\mathrm{ZA}$ & 1.540 & Kg & 3.500 & 5.390 .000 \\
\hline & & 1 & ZaK & 350.000 & 350.000 & & Pupuk & 155 & & & \\
\hline & Kalsiu & 10 & $\mathrm{Ko}$ & & & & TSP & 1.155 & Kg & 6.500 & 7.507 .500 \\
\hline & $\mathrm{m}$ & 10 & Kg & 15.000 & 150.000 & & Pupuk & 1155 & $\mathrm{Kg}$ & & \\
\hline & Borate & 8 & $\mathrm{Kg}$ & 20.000 & 160.000 & & KCL & & Ng & 7.000 & 8.085 .000 \\
\hline & Regen & 4 & Btl & 35.000 & 140.000 & & $\begin{array}{l}\text { Pupuk } \\
\text { SS }\end{array}$ & 11 & Zak & 350.000 & 3.850 .000 \\
\hline & $\begin{array}{l}\text { Lannat } \\
\mathrm{e}\end{array}$ & 4 & $\mathrm{Bh}$ & 35.000 & 140.000 & & $\begin{array}{l}\text { Kalsiu } \\
\mathrm{m}\end{array}$ & 110 & $\mathrm{Kg}$ & 15.000 & 1.650 .000 \\
\hline & $\begin{array}{l}\text { Termo } \\
\text { stok }\end{array}$ & 4 & Btl & 35.000 & 140.000 & & Borate & 88 & $\mathrm{Kg}$ & 20.000 & 1.760 .000 \\
\hline
\end{tabular}




\begin{tabular}{|l|l|r|r|r|r|} 
& Regen & 44 & Btl & 35.000 & 1.540 .000 \\
\hline & $\begin{array}{l}\text { Lannat } \\
\text { e }\end{array}$ & 44 & Bh & 35.000 & 1.540 .000 \\
\hline & $\begin{array}{l}\text { Termo } \\
\text { stok }\end{array}$ & 44 & Btl & 35.000 & 1.540 .000 \\
\hline $\begin{array}{l}\text { Convid } \\
\text { er }\end{array}$ & 44 & Bh & 35.000 & 1.540 .000 \\
\hline $\begin{array}{l}\text { Gandas } \\
\text { il }\end{array}$ & 44 & Bh & 30.000 & 1.320 .000 \\
\hline $\begin{array}{l}\text { Antoni } \\
\text { k }\end{array}$ & 22 & Bh & 55.000 & 1.210 .000 \\
\hline $\begin{array}{l}\text { Antrac } \\
\text { ol }\end{array}$ & 22 & Bh & 50.000 & 1.100 .000 \\
\hline & 11 & Btl & 60.000 & 660.000 \\
\hline $\begin{array}{l}\text { Rantu } \\
\text { ponda }\end{array}$ & 11 & Ltr & 75.000 & 825.000 \\
\hline $\begin{array}{l}\text { Pupuk } \\
\text { Kompo } \\
\text { s }\end{array}$ & 450 & Zak & & \\
\hline & \multicolumn{3}{|c|}{ Jumlah total } & & $\mathbf{8 8 . 1 9 1 . 5 0 0}$ \\
\hline
\end{tabular}

Sumber : Analisis Data Priemer Diolah

Berdasarkan tabel 6 tersebut, dapat diketahui bahwa rata-rata biaya bibit, pupuk, dan peptisida yang dikeluarkan petani pepaya Calina IPB 9 di Kecamatan Panyabungan Barat, Kabupaten Mandailing Natal sampai 7 bulan dibutuhkan biaya sebesar Rp. 29.921.500, sampai 9 bulan dibutuhkan biaya sebesar Rp. 32.489.000, sampai 11 bulan dibutuhkan biaya sebesar Rp. 36.081.500, sampai 13 Bulan membutuhkan biaya sebesar Rp 44.174.000, dan biaya rata-rata biaya bibit, pupuk, dan peptisida yang dikeluarkan petani pepaya Calina IPB 9 untuk 1 priode musim tanam (36 bulan) sebesar Rp. 88.191.500 . Untuk rata-rata perhektar lahan dibutuhkan bibit 1.800 batang, dengan jarak tanam antara tanaman satu dengan yang lain $2 \mathrm{M}$ antara bedengan satu dengan bedengan lain yaitu 3 M. ( 2 x 3 M) itu sudah termasuk penyulaman atau mengganti tanaman yang mati.

\section{Biaya total (total $\cos t=\mathbf{T C})$}

Untuk menghitung biaya total pertama yang dilakukan yaitu menghitung biaya tetap, biaya tetap meliputi, peralatan/perlengkapan dan sewa lahan. Biaya tetap yang dibutuhkan untuk 12 bulan sebesar Rp. 10.000.000 dan untuk 36 bulan sebesar Rp. 27.000.000. selanjutnya kita menghitung biaya di total biaya
Variabel Cost (Biaya tidak tetap) yaitu antara lain biaya tenaga kerja, pupuk, bibit, dan, pestisida. Untuk biaya rata-rata yang dikeluarkan oleh petani responden budidaya pepaya Calina IPB 9 dalam 9 bulan sebesar Rp. 54.789.000, selama 11 bulan sebesar Rp. 61.581.500, selama 13 bulan Rp. 72.874.000, dan Selama 36 bulan Rp. 153.691.500. Untuk mendapat Biaya total (Total Cost $=\mathrm{TC}$ ) digunakan rumus :

$$
\mathrm{TC}=\mathrm{FC}+\mathrm{VC}
$$

Jadi dapat kita hitung Biaya Total seperti pada tabel 7 .

Tabel 7. Rata-Rata Biaya Total (total cost =TC), Usaha budidaya Pepaya Calina IPB 9 di Kecamatan Panyabungan Barat, Kabupaten Mandailing Natal

\begin{tabular}{|c|c|c|c|}
\hline No. & Uraian & $B \ln$ & Jumlah (Rp) \\
\hline \multirow[t]{2}{*}{1} & $\begin{array}{l}\text { Biaya tidak tetap } \\
\text { (Variabel } \\
\text { Cost=VC) }\end{array}$ & \multirow[t]{2}{*}{7} & 49.021 .500 \\
\hline & $\begin{array}{l}\text { Biaya tetap (Fixed } \\
\text { cost=FC) }\end{array}$ & & 10.000 .000 \\
\hline \multicolumn{3}{|c|}{ Jumlah Total } & 59.021 .500 \\
\hline \multirow[t]{2}{*}{2} & $\begin{array}{l}\text { Biaya tidak tetap } \\
\text { (Variabel } \\
\text { Cost=VC) }\end{array}$ & \multirow[t]{2}{*}{9} & 54.789 .000 \\
\hline & $\begin{array}{l}\text { Biaya tetap (Fixed } \\
\text { cost=FC) }\end{array}$ & & 10.000 .000 \\
\hline \multicolumn{3}{|c|}{ Jumlah Total } & 64.789 .000 \\
\hline \multirow[t]{2}{*}{3} & $\begin{array}{l}\text { Biaya tidak tetap } \\
\text { (Variabel } \\
\text { Cost=VC) }\end{array}$ & \multirow[t]{2}{*}{11} & 61.581 .500 \\
\hline & $\begin{array}{l}\text { Biaya tetap (Fixed } \\
\text { cost=FC) }\end{array}$ & & 25.500 .000 \\
\hline \multicolumn{3}{|c|}{ Jumlah Total } & 87.081 .500 \\
\hline \multirow[t]{2}{*}{4} & $\begin{array}{l}\text { Biaya tidak tetap } \\
\text { (Variabel } \\
\text { Cost=VC) }\end{array}$ & \multirow[t]{2}{*}{13} & 72.874 .000 \\
\hline & $\begin{array}{l}\text { Biaya tetap (Fixed } \\
\text { cost=FC) }\end{array}$ & & 18.500 .000 \\
\hline \multicolumn{3}{|c|}{ Jumlah Total } & 91.374.000 \\
\hline \multirow[t]{3}{*}{5} & $\begin{array}{l}\text { Biaya tidak tetap } \\
\text { (Variabel } \\
\text { Cost=VC) }\end{array}$ & \multirow[t]{2}{*}{36} & 153.691 .500 \\
\hline & $\begin{array}{l}\text { Biaya tetap (Fixed } \\
\text { cost=FC) }\end{array}$ & & 27.000 .000 \\
\hline & Jumlah total & & 180.691 .500 \\
\hline
\end{tabular}




\section{Analisis Penerimaan Usaha budidaya} (TR)

\section{Penerimaan}

usaha budidaya adalah nilai produksi yang diperoleh dalam suatu usaha budidaya. Menurut Shinta A $(2011 ; 83)$ penerimaan usaha adalah perkalian antara produksi yang dihasilkan dengan harga jual.

Penerimaan usaha budidaya pepaya Calina IPB 9 merupakan jumlah total uang yang diterima dari hasil penjualan pepaya oleh petani yang dinyatakan dalam rupiah.

Tanaman pepaya panennya tidak serentak sesuai dengan kematangan buah pepaya dan petani menjual produksinya dengan harga jual yang berbedabeda untuk mengetahui frekuensi panen dan penjualan bisa dilihat di tabel 8 dibawah ini sebagai berikut :

Tabel 8. Rata-Rata Penerimaan Usaha budidaya Pepaya Calina IPB 9 di Kecamatan Panyabungan Barat, Kabupaten Mandailing Natal

\begin{tabular}{|c|c|r|r|r|}
\hline No & Bln & $\begin{array}{c}\text { Rata- } \\
\text { rata } \\
(\mathbf{K g}) / \mathbf{H a}\end{array}$ & $\begin{array}{c}\text { Jumlah } \\
(\mathbf{R p})\end{array}$ & \multicolumn{1}{|c|}{ Total (Rp) } \\
\hline 1 & 7 & 1.100 & 2.750 .000 & 2.750 .000 \\
\hline 2 & $8 \mathrm{~s} / \mathrm{d} 9$ & 9.800 & 24.500 .000 & 27.250 .000 \\
\hline 3 & $\begin{array}{c}10 \mathrm{~s} / \mathrm{d} \\
11\end{array}$ & 22.500 & 56.250 .000 & 83.500 .000 \\
\hline 4 & $\begin{array}{c}12 \mathrm{~s} / \mathrm{d} \\
13\end{array}$ & 24.000 & 60.000 .000 & 143.500 .000 \\
\hline 5 & $\begin{array}{c}14 \mathrm{~s} / \mathrm{d} \\
36\end{array}$ & 183.200 & 458.000 .000 & 601.500 .000 \\
\hline
\end{tabular}

Sumber : Analisis Data Priemer Diolah

Jumlah rata-rata produksi buah pepaya california di Kecamatan Panyabungan Barat, Kabupaten Mandailing Natal perhektar dapat dilihat pada tabel 8 dan harga yang diterima oleh petani pada Rp.2.000 per Kg sampai Rp. 3.000 Per Kg oleh sebab itu kita ambil harga rata-rata Rp. 2.500 per Kg. Rp. 601.500.000 rata-rata total penerimaan petani pepaya california di Kecamatan Panyabungan Barat, Kabupaten Mandailing Natal, pada priode 1 musim tanam (36 bulan).

\section{Analisis Pendapatan $(\pi)$}

Usaha budidaya adalah suatu kegiatan ekonomi yang di tujukan untuk menghasilkan output (penerimaan), dengan input fisik, tenaga kerja, dan modal sebagai korbanannya. Penerimaan total adalah nilai produksi usaha budidaya dalam jangka waktu tertentu. Pengeluaran total usaha budidaya adalah semua nilai input yang dikeluarkan dalam proses produksi. Pendapatan usaha budidaya merupakan selisih antara penerimaan dengan semua biaya yang dikeluarkan dan bila dirumuskan sebagai berikut : $\pi=\mathrm{TR}-\mathrm{TC}$

Sehingga diperoleh pendapatan usaha budidaya pepaya Calina IPB 9 di Kecamatan Panyabungan Barat, Kabupaten Mandailing Natal sebagai berikut.

Tabel 9. Rata-Rata Pendapatan ( $\pi$ ) Usaha budidaya Pepaya Calina IPB 9 di Kecamatan Panyabungan Barat, Kabupaten Mandailing Natal

\begin{tabular}{|l|r|r|r|}
\hline BIn & $\begin{array}{c}\text { Penerimaan } \\
\text { TR (Rp) }\end{array}$ & $\begin{array}{c}\text { Total Biaya } \\
\text { TC }(\mathbf{R p})\end{array}$ & $\begin{array}{c}\text { Pendapatan } \\
\boldsymbol{\pi} \\
(\mathbf{R p}) / \mathbf{H a}\end{array}$ \\
\hline 7 & 2.750 .000 & 59.021 .500 & -56.271 .500 \\
\hline 9 & 27.250 .000 & 64.789 .000 & -37.539 .000 \\
\hline 11 & 83.500 .000 & 71.581 .500 & 11.918 .500 \\
\hline 13 & 143.500 .000 & 91.374 .000 & 52.126 .000 \\
\hline 24 & 396.000 .000 & 135.436 .500 & 260.563 .500 \\
\hline 36 & 601.500 .000 & 180.691 .500 & 420.808 .500 \\
\hline
\end{tabular}

Sumber : Analisis Data Priemer Diolah

Dari tabel 9 di atas dapat disimpulkan bahwa rata-rata pendapatan usaha budidaya pepaya Calina IPB 9 per Ha di Kecamatan Panyabungan Barat, Kabupaten Mandailing Natal untuk 1 priode (36 bulan) adalah Rp. 420.808.500 untuk pendapatan tersebut diperoleh dari total penerimaan(TR) dikurangi dengan total biaya (TC).

\section{Periode pembayaran kembali (Pay back periode)}

Pay back periode adalah priode waktu untuk mengetahui kapan pada bulan atau tahun keberapa (kapankah) seluruh biaya usaha budidaya pepaya Calina IPB 9 dapat kembali. Seluruh petani pepaya menjual produksinya 
tiap minggu atau perperiodik. Dan untuk mengetahui kapan biaya produksi usaha budidaya pepaya dapat kembali. Kita bisa melihat tabel 10 dibawah ini

Tabel 10. RC-Ratio

\begin{tabular}{|c|c|c|c|}
\hline $\begin{array}{c}\text { BI } \\
\mathbf{n}\end{array}$ & $\begin{array}{c}\text { Penerimaa } \\
\mathbf{n} \text { TR (Rp) }\end{array}$ & $\begin{array}{c}\text { Total } \\
\text { Biaya TC } \\
\text { (Rp) }\end{array}$ & $\begin{array}{c}\text { RC- } \\
\text { Ratio }\end{array}$ \\
\hline $\mathbf{1}$ & $\mathbf{2}$ & $\begin{array}{c}\mathbf{3 = 2 . 5 0 0} \mathbf{x} \\
(\mathbf{2})\end{array}$ & $4=2 / 3$ \\
\hline 7 & 2.750 .000 & 59.021 .500 & 0,05 \\
\hline 9 & 27.250 .000 & 64.789 .000 & 0,42 \\
\hline 11 & 83.500 .000 & 71.581 .500 & 1,17 \\
\hline & 143.500 .00 & & \\
13 & 0 & 91.374 .000 & 1,57 \\
\hline & 396.000 .00 & 135.436 .50 & \\
24 & 0 & 0 & 2,92 \\
\hline 36 & 601.500 .00 & 180.691 .50 & \\
0 & 0 & 0 & 3,33 \\
\hline
\end{tabular}

Sumber : Analisis Data Priemer Diolah

Dalam perhitungan pay back periode akan di jelaskan dibawah ini sebagai berikut:

1. Pada tanaman umur 0-7 bulan petani pepaya california masih menderita kerugian karena TC $>$ TR (total biaya yaitu Rp. 59.021.500> Penerimaan Rp. 2.750.000)

2. Pada tanaman umur 11 bulan petani sudah bisa mengembalikan modal atau (BEP) dan usaha budidaya sudah memberikan keuntungan tapi keuntungannya belum layak karena R/C Ratio baru mencapai 1,17) pendapatan untung Rp. 11.918.500

3. Untuk tanaman berumur 13 bulan usaha budidaya efisien (menguntungkan dan layak untuk diusahakan karna $\mathrm{R} / \mathrm{C}=1,57$ ( R/C Ratio > 1,3) atau sudah memberikan keuntungan sebesar Rp 52.126.000 Untuk lebih jelasnya bisa dilihat di tabel 9 dan tabel 10.

Dengan demikian dari perhitungan Pay back priode usaha budidaya pepaya Calina IPB 9 di Kecamatan Panyabungan Barat, Kabupaten Mandailing Natal pada umur tanaman ke sebelas bulan sudah mencapai BEP (atau mencapi titik impas)

\section{Analisis Imbangan Biaya dan Penerimaan (R/C Ratio)}

Analisis ini digunakan untuk mengetahui rasio keuntungan antara penerimaan dengan pengeluaran. Suatu usaha dikatakan efisien secara ekonomis apabila rasio output terhadap inputnya lebih menguntungkan dari usaha lain. Return and Cost Ratio (R/C Ratio) merupakan perbandingan antara lain output dengan pengeluaran usahatani.

Rasio pendapatan terhadap biaya merupakan perbandingan antara total penerimaan yang diperoleh dari setiap satuan uang yang dikeluarkan dalam proses produksi usahatani.

$\mathrm{R} / \mathrm{C}$ Ratio merupakan perbandingan antara total penerimaan(TR) dengan total biaya (TC). Menurut (Simatupang 2002) dan (Rusastra 1996) didalam (Siregar dan sumaryanto 2003), mengemukakan bahwa beberapa peneliti mengatakan usahatani suatu komoditas dapat bertahan dan dikatakan layak jika penerimaan bersih bagi pengelola paling sedikit mencapai $20 \%$ dari biaya yang dikeluarkan. Proporsi atau nilai penerimaan dianggap sudah cukup mewakili seorang petani sebagai pengelola usaha. Perhitungan RC Ratio usaha budidaya pepaya Calina IPB 9 di Kecamatan Panyabungan Barat, Kabupaten Mandailing Natal. akan di jelaskan di bawah ini sebagai berikut :

1. Total Penerimaan (TR). = Rp. 143.500.000

2. Total Biaya. $(\mathrm{TC})=\mathrm{Rp} .91 .374 .000$

3. $\mathrm{R} / \mathrm{C}$ Rasio $=1,57$

4. Pay back priode Pada bulan ke tiga belas Melihat nilai R/C Ratio sebesar 1,57 maka dapat diartikan bahwa setiap penggunaan biaya sebesar 1 satuan nilai maka diperoleh penerimaan sebesar 1,57 satuan nilai. Dan untuk R/C Rasio 1 priode (36 Bulan) Usaha budidaya pepaya Calina IPB 9 adalah 3,33 dan 
rata-rata Pendapatan $\pi$ adalah Rp. 420.808 .500 untuk per Ha. dengan demikian dari perhitungan R/C Ratio usaha budidaya pepaya Calina IPB 9 di Kecamatan Panyabungan Barat, Kabupaten Mandailing Natal diatas, berarti usahatani efisien atau menguntungkan dan layak untuk diusahakan sesuai dengan kriteria dalam usahatani bila R/C Ratio > 1,2.

\section{PENUTUP}

\section{Kesimpulan}

Berdasarkan hasil kesimpulan dan hasil analisa pada usaha budidaya pepaya Calina IPB 9 di Kecamatan Panyabungan Barat, Kabupaten Mandailing Natal dapat disimpulkan sebagai berikut :

1. Rata-rata total biaya atau Total Cost (TC), untuk satu hektar lahan tanaman pepaya california di Kecamatan Panyabungan Barat, Kabupaten Mandailing Natal untuk 1 priode (36 bulan) adalah sebesar Rp. 180.691.500;

2. Jumlah produksi rata-rata di tingkat petani Kecamatan Panyabungan Barat pada tanaman umur 7 bulan sebanyak 1.100 tanaman pada umur 8 s/d 9 bulan sebanyak $9.800 \mathrm{Kg}$ tanaman umur $10 \mathrm{~s} / \mathrm{d} 11$ bulan sebesar $22.500 \quad \mathrm{Kg}$ dan jumlah keseluruhan(1 Priode adalah $240.600 \mathrm{Kg}$. Dengan harga buah pepaya Calina IPB 9 per Kg dipasaran pada adalah sebesar Rp.2.000 s/d Rp.3.000 maka diperoleh jumlah penerimaan yaitu sebesar Rp. 601.500.000;

3. Pendapatan usahatani pepaya california di Kecamatan Panyabungan Barat Kabupaten pada 1 priode (36 bulan) adalah sebesar Rp. 420.808.500;

4. Pay Back Preode (PBP) usahatani pepaya california usahatani pepaya california di Kecamatan Panyabungan Barat, Kabupaten Mandailing Natal pada saat tanaman umur 11 bulan sudah melebihi BEP dan sudah memberikan keuntungan yaitu sebesar $\mathrm{Rp}$. 11.918.500 atau 1,17 karena untuk ukuran kelayakan menurut Simatupang (2002) dan Rusatara (1996) dalam Siregar Masdjidin dan Sumaryanto (2003) adalah 1,2 dari biaya yang dikeluarkan;
5. Pada pay back priode tanaman berumur 13 bulan yang memberikan keuntungan layak (efisien) dengan R/C Ratio sebesar 1,57. Diatas RC Ratio kaidahnya yaitu R/C Ratio $>1,2$

6. Pada umur tanaman ke 13 bulan Nilai dari $\mathrm{R} / \mathrm{C}$ Ratio sebesar 1,57 maka dapat diartikan bahwa setiap penggunaan biaya sebesar 1 satuan nilai maka diperoleh penerimaan sebesar 1,57 satuan nilai dengan demikian dari perhitungan R/C Ratio usahatani pepaya Calina IPB 9 di Kecamatan Panyabungan Barat Kabupaten Mandailing Natal diatas, berarti usahatani efisien atau menguntungkan dan layak untuk diusahakan.

\section{Saran}

Untuk mencapai hasil yang maksimal diperlukan pemupukan dan perawatan yang rutin terutama dimusim penghujan, jangan sampai ada genangan air karena akar pepaya akan mengalami pembusukan dan pepaya akan mati kalau dibiarkan.

\section{DAFTAR PUSTAKA}

[1] Arifin, 2005. Teori Keuangan dan Pasar Modal. Yogyakarta: Ekosinia.

[2] Arikunto, S. 2012. Prosedur Penelitian Suatu Pendekatan Praktek, Jakarta :Rieneka Cipta, Cet III.

[3] Isnawan Y, 2011. Budidaya Pepaya California.

http://epetani.pertanian.go.id/budidaya/ budidayapepayacalifornia-8481 Agustus 2014].

[4] Purnadi, P., Widhiandono, H., \& Darmawan, A. (2017). Penyuluhan kewirausahaan dan cara penanaman pepaya california pada lahan kosong untuk meningkatkan kesejahteraan buruh tani. Media Ekonomi, 17(1).

[5] Shinta A, 2011. Ilmu Usaha budidaya, (Malang: Penerbit UB - Press).

[6] Siregar Masdjidin dan Sumaryanto, (2003), Analisis Daya Saing Usahatani kedelai di DAS Brantas,Pusat Penelitian dan Pengembangan Sosial Ekonomi 
Pertanian,Deptan,Jurnal

Agroekonomi

volume 21 nomor 1 , Bogor.

[7] Soekartawi, 2006. Analisis Usaha budidaya. Jakarta. Universitas Indonesia.

[8] Sumaryanto, Wahida dan M. Siregar. 2003. Determinan Efisiensi Teknis Usaha budidaya di Lahan Sawah Irigasi. Jurnal Agro Ekonomi, 21 (1):72-96.

[9] Sujiprihati S, Suketi K. 2014. Budidaya Pepaya Unggul. Ed ke-3. Penebar Swadaya, Jakarta.

[10] Szulecka, J., Obidzinski, K., \& Dermawan, A. (2016). Corporate-society engagement in plantation forestry in Indonesia: Evolving approaches and their implications. Forest Policy and Economics, 62, 19-29. 